\title{
Caregiver's assistance in the self-care functional skills in children with low vision age 2 to 3 years
}

\author{
Assistência do cuidador nas habilidades funcionais de \\ autocuidado em crianças com baixa visão de 2 a 3 anos de idade
}

Janaine Brandão1, Gabriel Antonio Nogueira Nascentes², Karina Pereira ${ }^{3}$

\begin{abstract}
Objective: To assess the caregiver assistance demand in the functional self-care skills in children with low vision. Methods: Fourteen children aged between two and three years, both genders, were allocated into two groups, low vision and normal vision. The Pediatric Evaluation of Disability Inventory (PEDI) was applied specifically to parties I (functional skills) and II (caregiver assistance) in the selfcare area. Results: There was no significant difference between children with low vision and normal vision in the functional skills $(t=0,655 ; p=0,525)$ and caregiver assistance level $(t=0,902 ; p=0,385)$. However, there was strong and position correlation between parties I and II in the self-care for children with low vision ( $r=+0,924 ; p=0,003)$ and moderate and position normal vision $(r=+0,790 ; p=0,035)$. Conclusion: The caregiver assistance demand in the self-care functional skills in children with low vision, between age two to three years, is within the normal standards of the PEDI, showing good functional performance, with the assistance of moderate to minimum.
\end{abstract}

Keywords: Low vision; Motor skills; Child

\section{RESUMO}

Objetivo: Avaliar a demanda de assistência do cuidador nas habilidades funcionais de autocuidado nas crianças com baixa visão. Métodos: Participaram 14 crianças com idade entre dois e três anos, ambos sexos, divididas em dois grupos: baixa visão e visão normal. O Inventário de Avaliação Pediátrica de Incapacidade (PEDI) foi aplicado especificamente às partes I (habilidades funcionais) e II (assistência do cuidador) na área de autocuidado. Resultados: Não houve diferença significativa entre crianças com baixa visão e visão normal nas habilidades funcionais $(\mathrm{t}=0,655 ; \mathrm{p}=0,525)$ e nível de assistência do cuidador $(\mathrm{t}=0,902 ; \mathrm{p}=0,385)$. Porém, houve correlação forte e positiva entre as partes I e II no autocuidado para crianças com baixa visão $(r=+0,924 ; p=0,003)$ e moderada e positiva para as com visão normal $(\mathrm{r}=+0,790 ; \mathrm{p}=0,035)$. Conclusão: $\mathrm{A}$ demanda de assistência do cuidador nas habilidades funcionais de autocuidado de crianças com baixa visão, entre dois a três anos de idade, está dentro dos padrões de normalidade do PEDI, apresentando bom desempenho funcional, com auxílio de moderada à mínima.

Descritores: Baixa visão; Destreza motora; Criança

\footnotetext{
1 Associação de Pais e Amigos Excepcionais, Uberaba, MG, Brazil.

2 Instituto Federal do Triângulo Mineiro, Uberaba, MG, Brazil.

${ }^{3}$ Universidade Federal do Triângulo Mineiro, Uberaba, MG, Brazil.

Research carried out at Universidade Federal do Triângulo Mineiro - UFTM, Uberaba, Minas Gerais, Brazil. Source to assist the research: Coordenação de Aperfeiçoamento de Pessoal de Nível Superior - CAPES.

The authors declare no conflicts of interests.

Received for publication 28/09/2016 - Accepted for publication 05/11/2016
} 


\section{INTRODUCTION}

$\mathbf{S}$ ight is one of the main senses for child development ${ }^{(1)}$, because it exerts great influence on the performance of functional activities of children. The visual capacity and skills development are closely linked as a result of the deprivation of vision in exploring the environment. ${ }^{(2)}$

There are more than 285 million people with visual impairment worldwide, with 39 million being blind and 246 million with low vision. ${ }^{(3)}$ In Brazil these data represent $18 \%$ of the population, with low vision having an incidence three times greater than the blindness. ${ }^{(4)}$ The visual impairment is an impairment of the eyes or in the pathways to drive the visual impulse that causes a decrease in the ability to see. It can be divided into two broad categories: blindness and low vision, which corresponds to the total or partial deprivation of the ability to see, respectively.(5) In Brazil, the leading cause of visual impairment in childhood is congenital glaucoma, followed by retinopathy of prematurity, macular retinochoroiditis for toxoplasmosis and congenital cataracts. ${ }^{(6,7)}$ Albinism can lead to hypopigmentation of the eyes due to the production of melanin, which is one of the main consequences of the low vision. ${ }^{(8)}$

Children with visual impairment have a late development of the functional skills of self-care and difficulty to carry out activities independently. ${ }^{(9-11)}$ In this case, the family plays a prominent role as promoter and supporter of independence and autonomy for the performance of the same..$^{(9,12,13)}$

In childhood, personal and functional actions are derived from experiences during the functional skills of self-care, such as bathing, feeding, clothing, among others. ${ }^{(14)}$ They express the first links of the child with the main caregiver. ${ }^{(15)}$

While performing daily activities, the child develops its independence, autonomy and self-confidence. ${ }^{(14,16)}$ No matter how rich is the genetic inheritance of the child, the safe experience, emotional history and gradual detachment from the caregiver so that the child acquires autonomy to perform everyday tasks can be fey to their development. ${ }^{(17)}$

However, the performance of self-care activities must be encouraged in children with low vision, independently and from sensory-motor experiences lived during bath, feeding, dressing or undressing, combing the hair and getting around, to make them safer and more confident. ${ }^{(14)}$

In order to know the impact that low vision can provide to the caregiver assistance necessary for children to carry out basic activities of self-care, this study aims at evaluating the demand for assistance from the caregiver in the functional self-care skills of the children with low vision of two to three years of age. The hypothesis is that children with low vision will have greater difficulties to perform self-care activities, needing greater assistance from the caregiver.

\section{Methods}

The present study is analytical, quantitative, and crosssectional. The selection of participants occurred from the criterion of convenience by difficulty in the screening process of the low vision group.

For this, it was necessary to accomplish a sample calculation using the software Diman 1. $0^{(18)}$, which determined a sample of at least seven individuals according to a study conducted with children in the same age group involving the similar context. ${ }^{(2)}$
Considering the functional ability of self-care, we used the values of the averages and standard deviation of each of the groups (control and low vision), as well as a confidence interval of $95 \%$ and test power (1-b) of $80 \%$.

This way, we invited 14 children aged between two and three and a half years of both genders whose parents or legal guardians agreed to participate in the study by signing an Informed Consent (TCLE). The children were divided into two groups: with visual impairment (low vision), and without visual impairment (normal vision). The group low vision presented the following inclusion criteria: ophthalmological diagnosis stating the visual impairment according to the medical record provided by the institutions, be enrolled in the institutions for visual stimulation care for more than six months, and absence of neurological changes or other associated pathologies compromising the child development. For the group normal vision, the criteria of the negative eye test was adopted, attesting normal ophthalmologic exam without visual impairments and absence of neurological diseases, congenital malformations, genetic syndromes, auditory deficit, or even any alteration that could influence or compromise the development of child. For standardization of both groups, the children should present independent march.

In order to collect data from the group low vision, the research was developed according to the consent and previous authorizations of two institutions specialized in the care of the visually impaired: Fundação Pró-Luz, in the city of Uberlândia, and Instituto de Cegos do Brasil Central (ICBC), in Uberaba, both located in the region of Triângulo Mineiro. The collection of children with normal vision followed the same criteria of the other institutions, but it was carried out in a kindergarten school in the city of Uberaba.

The Pediatric Disability Assessment Inventory (PEDI) was the instrument adopted, as it is a questionnaire translated and validated in Brazil aiming at evaluating the functional performance of children aged from six months to seven years and six months in the areas of self-care, mobility and social function. Considering the areas involved, PEDI has three parts informing important aspects of the development: functional skills (part I), caregiver assistance (part II), and environmental modifications (part III). ${ }^{(19)}$ However, this study used only parts I and II with respect to the area of self-care.

The 73 items that make up the self-care activities found in functional skills correspond to the ability of a child to perform or not a certain activity, that is, when they are able to perform they get one point (1) and when they do not they are not scored (0). With caregiver assistance, the activities are restricted to seven questions, but the score is established by the levels of assistance that the child gets while performing it, following an ordinal scale from 0 to 5 , in which 0 (zero) represents the total dependence, from 1 to 3 the child demands assistance ranging from minimal (1), moderate (2) to maximum (3), (4) just needs supervision, and (5) is independence during tasks. ${ }^{(19)}$

Among the scores generated by the questionnaire PEDI, the gross and normative scores of part I and II were used in this study related to the area of self-care. The gross score represents the sum of the score at the end of each of the parts, whereas the normative score corresponds to the value of the gross score related to age. According to the creators of this instrument, the normality standards correspond to the normative score between 30 and 70 found in Brazilian children, with 50 being the average standard. ${ }^{(19)}$ 
Prior to data collection, we carried out a study and training on the questionnaire PEDI, in order to adjust the time and avoid possible doubts that could arise during the implementation process, thus avoiding complications in the future.

After the training, we contacted the institutions Fundação Pró-Luz and ICBC to select first the children with low vision for the criteria established for this group. The parents or legal guardians of the children were contacted by telephone, and invited to participate in the study according to their availabilities. At this moment, the sensitization with the same ones was made in order to clarify the objectives and the procedures to be carried out by the study. On the day of the collections we obtained the signatures of the TCLE. Children with normal vision were selected after the collection of the group low vision, keeping the convenience criteria established for the study. The contact procedures, invitation and clarification with the parents or legal guardians were kept according to the group low vision.

All the collections were made by the same researcher, with an average duration of 20 minutes, in a single day The instrument was applied individually so that there was no contact among the parents. In order to ensure the reliability and trustworthiness of the answers, all the interviews were recorded using an audio recorder $\left(\mathrm{COBY}^{\circledR}\right)$.

This study considered as independent variables the low vision and the normal vision, and the dependent ones were the gross and normative scores of PEDI regarding the functional skills and assistance from the caregiver in self-care.

The statistical analyses were performed using the software Statistica 10.0, and the results showing a significance level (p) less than 0.05 were considered significant. For all the following analysis, the numerical data was expressed as means, and the standard deviation as standardization. The numerical data was submitted to the Shapiro-Wilk test for normality and to the Levene test for homogeneity. The data showed normal distribution, and the homogeneous variances (functional skills and caregiver assistance, personal care, lower garment, use of container to drink, shoes/socks, and bowel control of functional skills) were compared by means of the parametric $t$-Student test, whereas the nonparametric data (feed, bath, upper garment, bathroom, urinary control and bowel control of caregiver assistance, food texture, use of utensils, oral care, hair care, nose care, wash the hands, wash the body and the face, clothes open in the front, zippers, pants, toilet tasks and urinary control of functional skills) were assessed by the Mann-Whitney test. In addition, the relation between the results obtained from the questionnaire was analyzed by the Pearson's correlation coefficient (functional skills and assistance from the caregiver). The categorical data was compared among children with low vision and normal vision by the Chi-square test with the Yates correction.

The study was approved by the Research Ethics Committee (CEP) of Universidade Federal do Triângulo Mineiro (UFTM) according to Opinion 2760/2013.

\section{Results}

Table 1 represents the characteristics of the low vision group according to age, gender, city and diagnosis.

In both groups, $100 \%$ of the interviews were held with mothers, $85.71 \%$ being of mothers of children with low vision who were housewives, and the same percentage was found in mothers of children with normal vision who worked outside the home.

According to figure 1, there was no significant difference for functional skills $(\mathrm{t}=0.655 ; \mathrm{p}=0.525)$ and the assistance from the caregiver $(\mathrm{t}=0.902 ; \mathrm{p}=0.385)$ among children with low vision and normal vision in self-care. Children with low vision presented values above 30 in functional skills $(46.61 \pm 12.99)$ and the assistance from the caregiver (43.64 \pm 9.08$)$, as well as children with normal vision $(50.29 \pm 7.14)$ and $(47.54 \pm 6.96)$, respectively. Both achieved higher scores in functional skills.

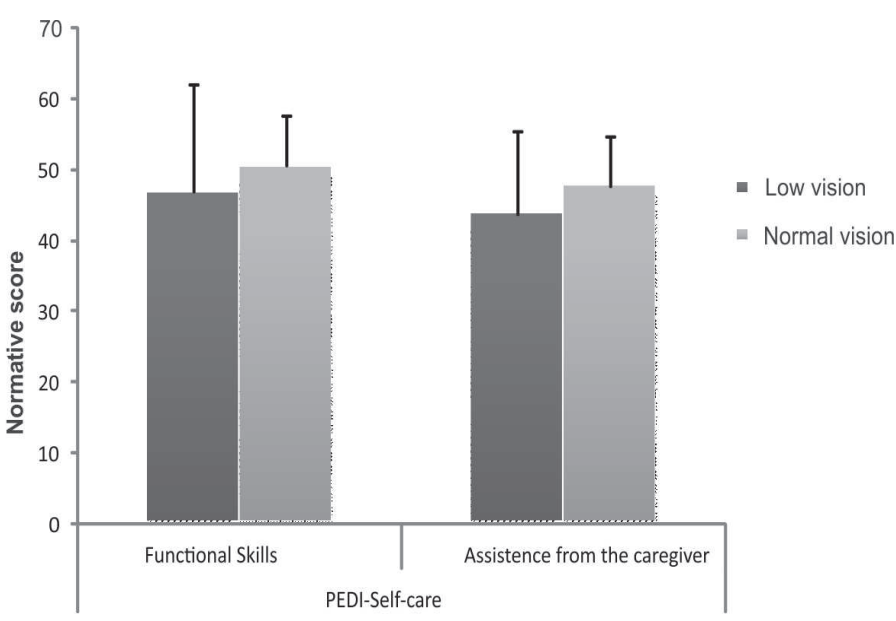

Figure 1: Comparison between functional skills and the assistance from caregiver in self-care between the groups low vision and normal vision.

Table 1

Characterization of the group low vision

\begin{tabular}{clllc}
\hline Children with low vision & \multicolumn{1}{c}{ Age } & Gender & City & Ophthalmological diagnosis \\
\hline $\mathbf{1}$ & 2 years & Male & Uberaba & Paralysis of the VI cranial nerve \\
$\mathbf{2}$ & 2 years 1 month & Female & Uberaba & Albinism \\
$\mathbf{3}$ & 2 years 4 months & Female & Uberaba & Albinism \\
$\mathbf{4}$ & 2 years 8 months & Male & Uberlândia & Bilateral congenital cataracts \\
$\mathbf{5}$ & 3 years 4 months & Female & Uberlândia & Retinopathy of prematurity \\
$\mathbf{6}$ & 3 years 6 months & Male & Uberlândia & Coloboma of retina, choroid and bilateral optic nerve \\
$\mathbf{7}$ & 2 years 11 months & Male & Uberlândia & Congenital toxoplasmosis \\
\hline
\end{tabular}


Figure 2 represents the correlations between assistance from the caregiver and functional skills for each group. There was a strong correlation for the children with low vision $(\mathrm{r}=+0.924$; $\mathrm{p}=0.003)$, and moderate for those with normal vision $(\mathrm{r}=+0.790$; $\mathrm{p}=0.035)$.

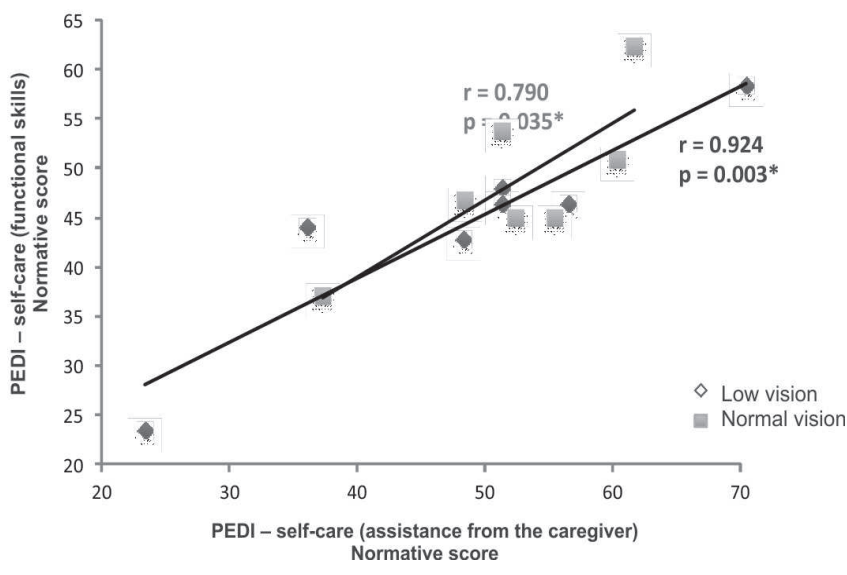

Figure 2: Correlation between functional skills and assistance from the caregiver in self-care (groups low vision and normal vision). $\mathrm{r}=$ correlation; $\mathrm{p}=$ significance level. $*$ Significant $\mathrm{p}$ value $(\mathrm{p}<0.05)$.

Figure 3 shows that there was no significant difference between the groups. By observing the children, it was found that for both groups the greater assistance of the caretaker (maximum and moderate) was in the bathroom, and the smallest (minimum and supervision) was in feeding.

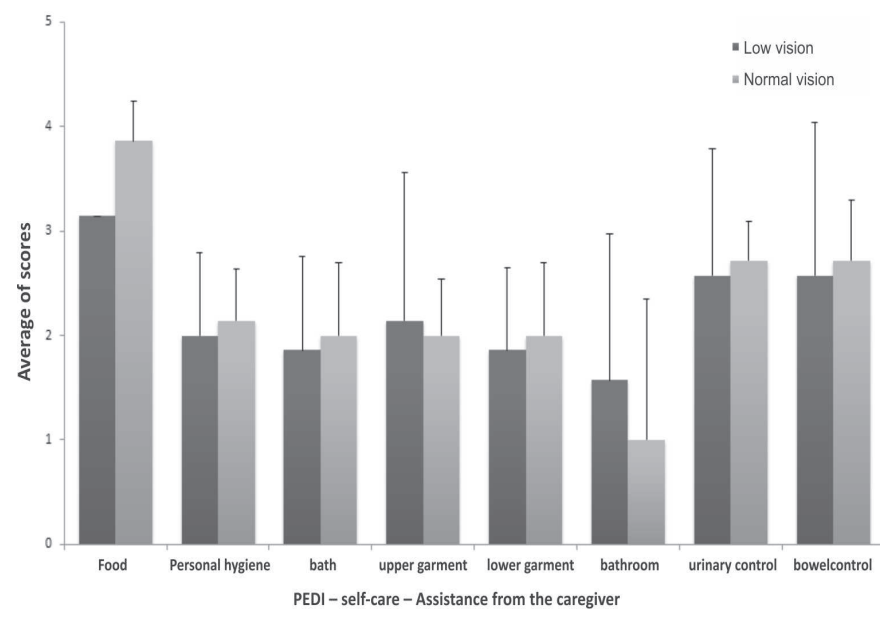

Figure 3: Average gross scores of assistance from the caregiver on self-care for groups low vision and normal vision. $=$ total dependence, $1=$ maximum assistance, $2=$ moderate assistance, $3=$ minimum assistance, $4=$ supervision and $5=$ independence.

In Figure 4, there was no significant difference either between the groups in the functional skills of self-care. Special attention to children with low vision who demonstrated better performance in functional skills than those with normal vision in garments open in the front part, pants, shoes/socks, toilet tasks, urinary and bowel control. The ability of greater difficulty was in zippers for both groups.

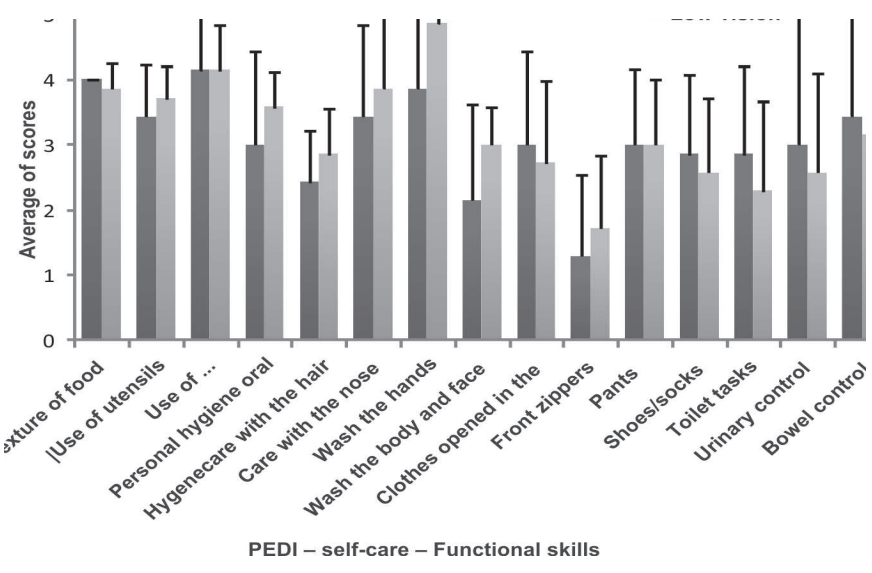

Figure 4: Average gross scores of functional skills on self-care for groups low vision and normal vision.

\section{DiscuSSION}

The use of standardized methods of evaluation about performance and dependence of children on their daily activities becomes essential for studies that seek to understand the development in its widest sense. ${ }^{(20,21)}$. According to a study, the questionnaire PEDI stands out as the most widely used method to evaluate the functional performance in daily activities in research involving children. ${ }^{(21)}$ Consequently, the questionnaire was selected for the present study.

The interviews with PEDI were 100\% carried out with the mothers of children from both groups. This finding is consistent with the study that reveals the close relationship of dependency between mother and child, especially in the early years of life, with the mother playing the role of primary responsibility in family relations. ${ }^{(22)}$ In addition to the responsibility factor, most $(85.71 \%)$ mothers of children with low vision didn't work outside the home, devoting their time to the care of their children. According to the authors, the interaction between mother and child with visual impairment must be considered essential to their development, as it is the first bond between the baby and the adult. ${ }^{(23)}$

Self-care activities are important for children's development, being essential in the acquisition of motor milestones, functional independence, autonomy, self-esteem and self-confidence of children. ${ }^{(24)}$

The differences between the results of children with low vision and normal vision were not significant. However, this fact represents a positive point, as children with low vision have good performance in the functional skills of self-care, and caregiver assistance level is compatible to children with normal vision, which do not confirm the hypothesis of the present study. These results go against the studies that claim that children with low vision have functional performance significantly lower in functional skills of self care, requiring greater caregiver assistance from the caregiver. ${ }^{(2,9,11)}$ We can suggest that the difference between the two groups occurred because all children with low vision receive visual stimulation more than six months before. According to the authors, stimulation in the first years of life of the visually impaired child favors child performance. ${ }^{(25)}$

The results of the functional skills and the assistance of the caregiver show that children with low vision have no delays in development due to obtaining a score within the normal 
standards (between 30 and 70) for Brazilian children with normal development. ${ }^{(19)}$ These results corroborate the findings of a study that examined the influences of home environment on functional skills and assistance from the caretaker in the mobility of children with low vision. ${ }^{(26)}$ The performance of children with low vision not only depends on visual impairment, but also on the demands required in daily activities. ${ }^{(13)}$

From the comparative analysis between the average values obtained in functional skills and assistance from the caregiver in self-care activities, we can see that both children with low vision and with normal vision presented a better score in the performance of functional skills of self-care than in the level of caregiver assistance. These results corroborate the study that analyzed two-year old children with and without low vision. ${ }^{(2)}$ However, it contradicts the authors when they observe that a single child with low vision at six years of age presents a higher score in caregiver assistance in relation to the functional skills in self-care activities. ${ }^{(10)}$

The correlation between functional skills and assistance from the caregiver was positive, being strong for children with low vision and moderate for those with normal vision. This strong correlation demonstrates that during the activities of self-care, the better performance of children with low vision in their functional abilities happened due to the lower demand of assistance from the caregiver. This result was similar to the findings of a study involving children with low vision in the same age group who observed a positive correlation, but moderate between functional skills and assistance from the caregiver in mobility. ${ }^{(26)}$ Thus, parents and caregivers should encourage children with visual impairment to perform their activities independently, in order to encourage the acquisition of new skills.

For both children, the bathroom task was the one that required further assistance from the caregiver, that is, moderate and maximum (Figure 3 ). This fact could be related to the age established for this study, two to three years, as a result of the acquisition of the urinary and bowel control. The opposite occurred for the task of feeding, in which only supervision or minimal assistance was required (Figure 3 ). In this case, the visual impairment did not interfere with the skills of recognizing the textures of the food and the use of eating and drinking utensils (Figure 4), thus favoring the less assistance from the caregiver.

Children with low vision and normal vision showed good performance in functional skills of dressing, toilet tasks, and urinary and bowel control, and greater difficulties with zippers (Figure 4). According to the study, such skill is developed between four and five years old. (27) Therefore, the age may be a factor influencing the performance of zippers and not the visual impairment.

As a proposal for future studies, it is suggested to perform longitudinal studies for continuous analysis of the functional performance, as well as interview other relatives other than the mother, teacher and/or child's therapist, in order to confirm or reveal results different from the mother's in the functional abilities and the assistance from the caregiver in the area of selfcare of the children.

\section{ConcLusion}

The demand for assistance from the caregiver in the functional skills of self-care of children with low vision in the age group from two to three years is within the normality standards of PEDI, showing good performance in the functional skills and assistance from the caregiver, with moderate to minimal assistance.

It is important to emphasize that even with visual impairment, children with low vision can show good functional performance if they are stimulated early by parents or legal guardians, as well as by the professionals involved.

\section{ACKNOWLEDGEMENTS}

We thank the parents of the children involved in the research for participation; the partner institutions of this project: Instituto de Cegos do Brasil Central (ICBC) in Uberaba/MG, and Fundação Pró-Luz in Uberlândia/MG; and Coordenação de Aperfeiçoamento de Pessoal de Nível Superior (CAPES) as a source of aid for research.

\section{RefERENCES}

1. Graziano RM, Leone CR. Problemas oftalmológicos mais freqüentes e desenvolvimento visual do pré-termo extremo. J Pediatr. 2005; 81(1Suppl.1): S95-S100.

2. Mancini MC, Braga MA, Albuquerque KA, Ramos TM, Chagas PS. Comparação do desempenho funcional de crianças com visão subnormal e crianças com desenvolvimento normal aos 2 e 6 anos de idade. Rev Ter Ocup Univ São Paulo. 2010; 21(3):215-22.

3. World Health Organization. Global data on visual impairments. Geneva: OMS; 2010; 2010.

4. Brasil. Instituto Brasileiro de Geografia Estatística. Censo demográfico 2010: resultados preliminares do universo; 2010. Brasília (DF): IBGE; 2010.

5. Cavalcanti RS, Silva JA. O desenvolvimento da criança deficiente visual e suas adaptações educacionais. Cad Multidisc Pós Grad UCP. 2010;1(2):171-89.

6. Brito PR, Veitzman S. Causas de cegueira e baixa visão em crianças. Arq Bras Oftalmol. 2010; 63(1):49-54.

7. Haddad MA, Lobato FJ, Sampaio MW, Kara-José N. Pediatric and adolescent population with visual impairment: study of 385 cases. Clinics. 2006;61(3):239-46.

8. Moreira LM, Moreira SC, Cabanelas IT, Rocha LM. Perfil do albinismo oculocutâneo no estado da Bahia. Rev Cir Méd Biol. 2007; 6(1): 69-75.

9. Corrêa GC, Santana VC. Avaliação do impacto de uma intervenção. Rev Ter Ocup. Univ São Paulo. 2014; 25(1): 43-50.

10. Endrizzi G, Oliveira AC, Cabanas A. Pediatric Evaluation of Disability Inventory: análise da eficácia no diagnóstico da dependência e da autonomia de criança com baixa visão nas atividades da vida diária. In: XII Encontro Latino Americano de Iniciação Científica e VIII Encontro Latino Americano de PósGraduação, 2008, São José dos Campos. Anais. São José dos Campos: Universidade do Vale do Paraíba; 2008.

11. Malta J, Endriss D, Rached S, Moura T, Ventura L. Desempenho funcional de crianças com deficiência visual, atendidas no Departamento de Estimulação Visual da Fundação Altino Ventura. Arq Bras Oftalmol. 2006, 69(4):571-4.

12. Arruda SM. Atividade de vida diária e deficiência visual. In: Sampaio MW, Haddad MA, Costafilho HA, Siaulys MO. Baixa visão e cegueira: os caminhos para a reabilitação, a educação e a inclusão. Rio de Janeiro: Cultura Médica/Guanabara Koogan. 2010.p.467-77.

13. Silva MR, Airoldi MJ. A influência do familiar na aquisição de habilidades funcionais da criança com deficiência visual. Rev Ter Ocup Univ São Paulo. 2014; 25(1):36-42. 
14. Bruno MM. O desenvolvimento integral do portador de deficiência visual - Da intervenção precoce a integração escolar. São Paulo: Laramara; 1993.

15. Mancini MC, Megale L, Brandão MB, Melo AP, Sampaio RF. Efeito moderador do risco social na relação entre risco biológico e desempenho funcional infantil. Rev Bras Saude Mater Infant. 2004; 4(1):25-34.

16. Motta MP. Atividades da vida diária: importante instrumento na habilitação do deficiente visual. Mundo Saúde. 2001; 25(4): 358-60.

17. Monteiro JA, Vasconcelos TB, Silva RL, Cavalcante LI. Avaliação do nível de independência nas atividades de vida diária da criança com paralisia cerebral: um estudo de caso. Cad Ter Ocup UFSCar. 2012; 20(1):129-41.

18. Arango HG. Bioestatística - teórica e computacional. 3a ed. Rio de Janeiro: Guanabara Koogan; 2009.

19. Mancini MC. Inventário de avaliação pediátrica de incapacidade (PEDI): manual da versão brasileira adaptada. Belo Horizonte: UFMG; 2005.

20. Teixeira NM, Costa IS. Apresentação dos principais instrumentos utilizados para avaliação do desenvolvimento motor de crianças com paralisia cerebral. Estação Científica - Especial "Fisioterapia". 2012; 1: 1-13.

21. Vasconcelos TB, Cavalcante LI. Avaliação das atividades de vida diária em crianças: uma revisão da literatura. Rev Ter Ocup Univ São Paulo. 2013; 24(3): 267-72.
22. Turiel E. Domain specificity in social interactions, social thoughts and social development. Child Develop. 2010; 81(3):720-6.

23. Cunha AC, Enumo SRF. Desenvolvimento da criança com deficiência visual (DV) e interação mãe-criança: algumas considerações. Psic. Saúde Doenças. 2003; 4(1): 33-46.

24. Silva VF, Medeiros JS, Silva MN, Oliveira LS, Torres RM, Ary ML. Análise do desempenho de autocuidado em crianças com síndrome de Down. Cad Ter. Ocup UFSCar. 2013; 21(1): 83-90.

25. França-Freitas ML, Gil MS. O desenvolvimento de crianças cegas e de crianças videntes. Rev Bras Educ Espec 2012; 18(3):507-26.

26. Lage JB, Nascentes GA, Pereira K. Influência dos estímulos ambientais domiciliares na mobilidade de crianças com baixa visão: habilidade funcional e assistência do cuidador. Rev Bras Oftalmol. 2016; 75(4): 290-5.

27. Pessoa JH. Desenvolvimento da criança, uma visão pediátrica. Rev Bras Med. 2003; 9(3):15-6.

\section{Corresponding author:}

Janaine Brandão Lage

Rua Capitão Domingos, 309, Bairro Abadia.

ZIP Code: 38025-010, Uberaba, Minas Gerais.

Email: ja.bl@terra.com.br 